DOI: https://doi.org/10.24127/ajpm.v10i2.3455

\title{
CAN BLENDED LEARNING HELP IMPROVE STUDENTS' CRITICAL THINKING SKILLS?
}

\author{
Syaiful Anwar ${ }^{*}$, Wahyu Setyaningrum² \\ ${ }^{1 *}, 2$ Pendidikan Matematika, Universitas Negeri Yogyakarta, DIY, Indonesia \\ *Corresponding author. \\ E-mail: $\quad$ syaifulanwar.2017@student.uny.ac.id ${ }^{1^{*}}$ \\ wahyu_setyaningrum@uny.ac.id ${ }^{2)}$
}

Received 05 January 2021; Received in revised form 15 June 2021; Accepted 29 June 2021

\begin{abstract}
The flow of information is currently spreading very quickly, and massively, so critical thinking skills are needed to obtain valid information. Based on the 2015-2019 Ministry of Education and Culture Strategic Plan, learning activities in Indonesia have not yet facilitated the development of students' critical thinking skills. One of the lessons that are thought to be able to improve student's critical thinking skills is blended learning (BL). Therefore, this experimental study aims to determine the effectiveness of BL in terms of students' critical thinking skills. Data were collected through written tests and interviews. This study involved 68 eighth-grade junior high school students. The main instrument in this study is a mathematics test (pre-test and post-test) which consists of five essay questions. The independent sample t-test was used to compare the difference in average scores between the experimental class and the control class, followed by using the normalized gain (n-gain) score from the pretest and posttest to test the effectiveness of BL in terms of students' critical thinking skills. Based on the independent sample t-test, there is a significant difference in the average value of critical thinking skills between the BL class and the conventional class. The average n-gain score for the experimental class (BL) is categorized as less effective. The average n-gain score for the control class (conventional) is included in the ineffective category. So in conclusion, the application of BL in mathematics learning is categorized as less effective in terms of critical thinking skills.
\end{abstract}

Keywords: Blended learning; critical thinking.

\begin{abstract}
Abstrak
Arus informasi saat ini menyebar dengan sangat cepat, dan masif, sehingga diperlukan keterampilan berpikir kritis untuk memperoleh informasi yang valid. Berdasarkan Renstra Kemendikbud 2015-2019, kegiatan pembelajaran di Indonesia belum memfasilitasi pengembangan kemampuan berpikir kritis siswa. Salah satu pembelajaran yang dianggap dapat meningkatkan kemampuan berpikir kritis siswa adalah blended learning (BL). Oleh karena itu, penelitian eksperimen ini bertujuan untuk mengetahui keefektifan BL ditinjau dari kemampuan berpikir kritis siswa. Pengumpulan data dilakukan melalui tes tertulis dan wawancara. Penelitian ini melibatkan 68 siswa kelas VIII SMP. Instrumen utama dalam penelitian ini adalah tes matematika (pre-test dan post-test) yang terdiri dari lima soal essai. Uji independent sample t-test digunakan untuk membandingkan perbedaan rata-rata skor antara kelas eksperimen dan kelas kontrol, dilanjutkan dengan menggunakan skor normalized gain (n-gain) dari pretest dan post-test untuk menguji keefektifan BL ditinjau dari kemampuan berpikir kritis siswa. Berdasarkan uji independent sample t-test, terdapat perbedaan yang signifikan nilai rata-rata kemampuan berpikir kritis antara kelas BL dan kelas konvensional. Rata-rata skor n-gain untuk kelas eksperimen (BL) dikategorikan kurang efektif. Rata-rata skor n-gain untuk kelas kontrol (konvensional) termasuk dalam kategori tidak efektif. Jadi kesimpulannya, penerapan BL dalam pembelajaran matematika dikategorikan kurang efektif ditinjau dari kemampuan berpikir kritis.
\end{abstract}

Kata kunci: Blended learning; critical thinking.

This is an open access article under the Creative Commons Attribution 4.0 International License 


\section{INTRODUCTION}

The current flow of information spreads very quickly, massively, and widely so that students' critical thinking skills are needed to obtain valid information. Critical thinking is the ability of students to think logically and reflectively which refers to information processing activities (Bassham, Irwin, Nardone, \& Wallace, 2011; Ebiendele Ebosele Peter, 2012; Facione, 2015; Kwan \& Wong, 2015; Nitko \& Brookhart, 2014). The purpose of critical thinking is specifically needed by students for activities (1) identifying, (2) analyzing, (3) making choices, (4) making decisions, (5) drawing conclusions, (6) solving problems, (7) reasoning, and (8) to prove (Al-Mubaid, 2014; Arends \& Kilcher, 2010; Facione, 2015; Johnson, 2002; Mason, 2008; Moore \& Parker, 2015).

Blended learning (BL) is a learning concept where the learning process combines face-to-face learning and online learning (Cheung, Kwok, Shang, Wang, \& Kwan, 2016; Cheung, Kwok, Ma, \& Yang, 2017; Clark \& James, 2012; Yeen-ju, Mai, \& Selvaretnam, 2015). Several studies have been conducted on BL and mathematics teaching such as Bazelais \& Doleck (2017), Giacumo \& Savenye (2019), Nuri (2019), based on research, it is shown that BL has a positive impact both in terms of students' cognitive and affective. In addition, according to Poon (2012), the online component of $\mathrm{BL}$ is a driving force for the development of critical thinking skills.

There has been no previous research examining the object of research at the junior high school level. Characteristics of junior high school students are still not able to think critically well. This research was conducted with the research object of junior high school students in DIY with the characteristics of superior school students or above average. BL is expected to improve the critical thinking skills of junior high school students.

Based on the 2015-2019 Ministry of Education and Culture Strategic Plan, learning activities in Indonesia have not yet facilitated the development of students' critical thinking skills. The process and student learning outcomes in Indonesia are still classified as poor, this is because learning has not been effective in facilitating the development of creativity, critical thinking skills, and student analysis (Kemdikbud, 2015). Therefore, learning is needed that helps improve students' critical thinking skills.

One of the lessons that are thought to improve students' critical thinking skills is BL. According to Jou, Lin, \& Wu (2016), the BL environment encourages the process of knowledge transformation among students so as to promote critical thinking skills. Research on the application of BL and critical thinking is needed to conclude the effect of BL on students' critical thinking (Giacumo \& Savenye, 2019; Monk, Guidry, Pusecker, \& Ilvento, 2019). This study aims to determine the effectiveness of BL in learning mathematics. Specifically, this study compares the effectiveness of BL using Google Classroom and traditional classrooms in terms of students' critical thinking skills.

\section{METHOD}

This research is a quasiexperimental study with a pretestposttest control design and an experimental group as illustrated in Figure 1. The subjects in this study were 
grouped into two groups, namely the experimental group (using BL method) and the control group (using conventional method).

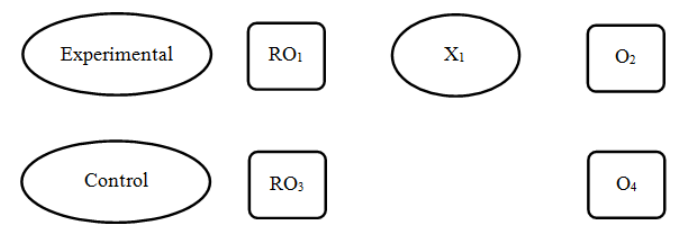

Figure 1. Research design

The subjects of this study were students of State Junior High Schools located in the city of Yogyakarta. The school use the 2013 Revised Curriculum. The student National Exam score interval in 2019 is between 285.5 and 303.5, which is included in the good category. Selection of research subjects using a purposive sampling technique. School selection is based on having a computer laboratory with an internet connection to support BL activities. The sample consisted of 66 students, 40 girls, and 26 boys that are divided into two classes, namely $8 \mathrm{~A}$ and $8 \mathrm{~B}$, aged 12 to 14 years. (mean $=13,8$; Standard Deviation= 0,4). These classes were randomly selected so that grade $8 \mathrm{~A}$ students served as the experimental group and grade $8 \mathrm{~B}$ students served as the control group.

The main instrument in this study is a mathematics test (pre-test and posttest) which consists of five essay questions. This instrument aims to collect data about students' critical thinking skills by comparing learning outcomes between BL students and students without BL. In the final session of the experiment, students carried out a post-test, both for the experimental group and the control group, to obtain data about students' critical thinking after treatment.
The validity of the instruments used in this study was content validity and quality validity. To ensure the content validity, clarity, and appropriateness of the instruments at the student level, the instrument items were reviewed by researchers and school teachers who had experience teaching mathematics. The test was piloted on 30 students in grade 8 in different classes. The instrument was tested using the Pearson product-moment correlation validity test using the SPSS program. Pearson's product-moment correlation test tested the correlation between the score of each item and the total score, the more positive the correlation between the item scores and the total score, the more valid it was. In this study, the correlation was significant at the 0.05 level (2-tailed). Reliability refers to the consistency of tests to measure students' critical thinking skills. The reliability of the test was measured using Cronbach's Alpha with a minimum value of 0.65 .

Besides, another instrument used to collect data in this study was interviews. After the implementation of BL, students were interviewed about their perceptions of Google classrooms. It is to get information about whether they prefer BL or conventional learning that they are used to.

Data about students' critical thinking skills were analyzed using descriptive analysis and inferential analysis. Descriptive analysis aims to provide a comparison of students' critical thinking skills pre-test and posttest between BL and conventional learning. The data presented are the mean, standard deviation, maximum and minimum values. In this study, the independent sample t-test was used to compare the difference in average scores between the experimental class 
and the control class, followed by using the normalized gain (n-gain) score from the pretest and posttest to test the effectiveness of BL in terms of students' critical thinking skills.

Thematic analysis is used to analyze the interview data which consists of six stages, including data transcription, data introduction, data coding, theme development, theme analysis, and revision. data familiarization refers to familiarizing the contents of the interview data, by reading the data again and again. Then proceed with labeling or coding means identifying data, sorting out important features that may be relevant to answer the research question. Then the labels or codes are double-checked to ensure that they echo the data. Interview to know students' preferences and perceptions about the use of BL with Google classroom in mathematics lessons.

\section{RESULTS AND DISCUSSION}

Critical thinking processes are closely related to the interpretation, analysis, and evaluation (Fong, Kim, Davis, Hoang, \& Kim, 2017; Herreid, Schiller, \& Herreid, 2012). Interpretation is the ability to understand or express meaning derived from experiences, situations, data, events, rules, procedures, or beliefs. The analysis is the ability to identify inferential and actual relationships between statements, questions, concepts, descriptions, or other forms of representation intended to express beliefs, judgments, experiences, reasons, information, or opinions. Evaluation is the ability to assess the credibility of a person's statements, experiences, situations, judgments, beliefs, or opinions, and the logical strength of actual inferential relationships. In this study, critical thinking skills are the ability to think logically and reflectively in the activities of collecting, using, trying, and analyzing information from various sources and using the results to conclude. Students are categorized as capable of critical thinking with indicators (a) interpretation, (b) analysis, and (c) evaluation.

BL can be defined as the integration of face-to-face learning experiences in the classroom with online learning experiences. However, this does not only combine face-to-face and online learning but it must consider both aspects as described in Table 1 . Offline learning classes are carried out with $100 \%$ face-to-face material with $0 \%$ online material submission. Online assisted learning is carried out with 71$99 \%$ of face-to-face materials with 1$29 \%$ of online material submissions. Blended learning is done with $30-79 \%$ face-to-face material with $21-70 \%$ sending material online. Online learning is carried out with $80-100 \%$ face-to-face material with $0-20 \%$ delivering material online. The blended learning used in this study consisted of $30-40 \%$ online and $60-70 \%$ face-to-face learning.

Table 1. Types of learning

\begin{tabular}{ccc}
\hline $\begin{array}{c}\text { Types of } \\
\text { learning }\end{array}$ & $\begin{array}{c}\text { Submission } \\
\text { of material } \\
\text { online }\end{array}$ & $\begin{array}{c}\text { Material } \\
\text { face to } \\
\text { face }\end{array}$ \\
\hline Offline class & $0 \%$ & $100 \%$ \\
$\begin{array}{c}\text { Online assisted } \\
\text { learning }\end{array}$ & $1-29 \%$ & $71-99 \%$ \\
$\begin{array}{c}\text { Blended learning } \\
\text { Online learning }\end{array}$ & $30-79 \%$ & $21-70 \%$ \\
\hline \multicolumn{3}{c}{ (Allen \& Seaman, 2009) }
\end{tabular}

Kashefi et al., (2012) argue that $\mathrm{BL}$ in mathematics has four aspects, as represented in Figure 2. (1) The task, duties as provided by the teacher both in the classroom or available on the website/ online. (2) Web assisted, 
students can access material via the web, where the web can contain notes, animations, forums, handouts, chats, journals, and other interactive activities and feedback. (3) Strategy, the delivery of learning materials can be synchronized through the online web such as chat rooms, e-mails, or discussion boards. (4) Assessment: teachers can assess summative and formative such as quizzes, test feedback, and written assignments.

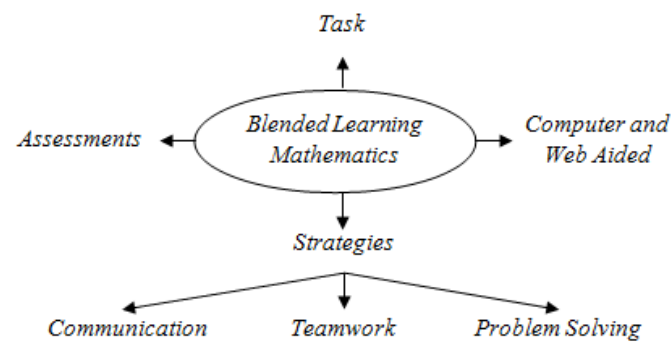

Figure 2.Model of blended learning (Kashefi et al., 2012)

For the experimental group, students learn mathematics in BL using Google classroom. Meanwhile, students in control group use convensional method mainly textbooks-based. The two requirements are identical in terms of the learning material being studied, the learning structure, the assignments completed by students, and the number of learning hours at school (5 meetings), each meeting is about 80 minutes long.

Students in both groups were faced with different teaching method, $\mathrm{BL}$, and conventional learning, but the material being taught was the same. BL is implemented with Google classroom as a learning management system. For one month, the experimental group students studied online learning in the computer laboratory twice. In online learning activities, the teacher provides material in the form of videos or sources from the internet and uploads them to Google classes. So that students can study at home before face-to-face learning. Students can watch and repeat the learning videos in Google classroom whenever they want. Before students start learning activities, they are asked to prepare notes and make questions that will be discussed during face-toface learning. During the learning activity, students take notes and then express their opinion during the discussion session. During the discussion session, the teacher provides the necessary explanations if needed. After online learning, scores are taken.

In the control group, students learn mathematics conventionally, which means face-to-face learning follows school regulations. As for conventional learning, there are three parts of the lesson, (1) opening or introducing learning materials (about 10 minutes); (2) an explanation of the material by the teacher or students working on the textbook either individually or in groups (about 50 minutes); (3) closing, reviewing the main ideas of learning guided by the teacher followed by the whole class (about 20 minutes). Assessment at the end of each lesson if necessary, carried out in the closing session.

The results of the instrument validity test using the Pearson productmoment correlation validity with a significant correlation at the 0.05 level (2-tailed) are presented in Table 2.

Table 2. Validity of instrument test

\begin{tabular}{cccc}
\hline No. & $\boldsymbol{r}_{\boldsymbol{x y}}$ & $\boldsymbol{r}_{\text {table }}$ & Information \\
\hline 1 & 0,793 & 0.436 & Valid \\
2 & 0,878 & 0.436 & Valid \\
3 & 0,614 & 0.436 & Valid \\
4 & 0,636 & 0.436 & Valid \\
5 & 0,590 & 0.436 & Valid \\
\hline
\end{tabular}

Based on Table 2 all items are valid. The results of the reliability test are presented in Table 3. 
DOI: https://doi.org/10.24127/ajpm.v10i2.3455

Table 3. Reliability of Instrument Test

\begin{tabular}{cc}
\hline Variable & $\begin{array}{c}\text { The reliability } \\
\text { coefficient of Posttest }\end{array}$ \\
\hline Critical thinking & 0.71 \\
\hline
\end{tabular}

The reliability of the instrument in this study was 0.71 (Table 3) which is included in high reliability.

Students who learn with BL have relatively better critical thinking skills compared to students who learn conventionally, this is based on the test results in the experimental class and the control class related to critical thinking skills in mathematics. It is implied by the mean and standard deviation of the students' scores as presented in Table 4. However, these data do not represent complete information for us to conclude, whether BL has a significant effect on students' critical thinking skills. To conclude this information, an independent sample t-test was performed followed by an n-gain score.

Table 4. Description of conceptual understanding

\begin{tabular}{ccccc}
\hline \multirow{4}{*}{ Description } & \multicolumn{4}{c}{ Result of research } \\
\cline { 2 - 5 } & \multicolumn{2}{c}{ Experiment } & \multicolumn{2}{c}{ Control } \\
\cline { 2 - 5 } & $\begin{array}{c}\text { Pre- } \\
\text { test }\end{array}$ & $\begin{array}{c}\text { Post- } \\
\text { test }\end{array}$ & $\begin{array}{c}\text { Pre- } \\
\text { test }\end{array}$ & $\begin{array}{c}\text { Post- } \\
\text { test }\end{array}$ \\
\hline $\begin{array}{c}\text { Sum of } \\
\text { student }\end{array}$ & 34 & 34 & 34 & 34 \\
$\begin{array}{c}\text { Sum of } \\
\text { score }\end{array}$ & 2277 & 2692 & 2395 & 2478 \\
Mean & 66.9 & 79.2 & 70.4 & 72.9 \\
$\begin{array}{c}\text { Standard } \\
\text { Deviation } \\
\text { Maximum } \\
\text { Score }\end{array}$ & 9,32 & 9,61 & 8,92 & 9,76 \\
Minimum & 82 & 97 & 86 & 90 \\
Score & 50 & 65 & 60 & 60 \\
\hline
\end{tabular}

The number of students in both classes is the same, there are 34 students taking the pretest and posttest. The total score of both classes increased after the pretest and posttest. In the experimental class, the average increase from 66.9 in the pretest to 79.2 in the post-test. In the control class, the average increase from 70.4 at the pretest to 72.9 at the posttest. The standard deviation increased from 9.32 at the pretest to 9.61 at the post-test in the experimental class. In the control class, the standard deviation increased from 8.92 at the pretest to 9.76 at the posttest. The maximum score increased from 82 on the pretest to 97 on the posttest in the experimental class. The maximum score increased from 86 on the pretest to 90 on the post-test in the control class. The minimum score increased from 50 on the pretest to 65 on the post-test in the experimental class. In the control class, the minimum score remains 60 on the pretest and 60 on the posttest. Based on Table 3. the average value of the experimental class is lower than the average value of the control class on the pretest, but the average value of the experimental class is superior to the average value of the control class on the posttest. This shows that the average value of the experimental class increased quite high compared to the control class.

An independent sample t-test was conducted to compare the difference in the average value of students' critical thinking skills between the experimental class and the control class. Then proceed with using the n-gain value from the pretest and posttest to determine the effectiveness of $\mathrm{BL}$ on students' critical thinking skills. The results of the independent sample t-test are presented in Table 5.

Tabel 5. The results of the independent sample t-test

\begin{tabular}{ccc}
\hline $\begin{array}{c}\text { Critical } \\
\text { Thinking } \\
\text { Skills Score }\end{array}$ & $\begin{array}{c}\text { Levene's Test } \\
\text { for Equality } \\
\text { of Variances }\end{array}$ & $\begin{array}{c}\text { T-test for } \\
\text { Equality of } \\
\text { Means }\end{array}$ \\
\cline { 2 - 3 } $\begin{array}{c}\text { Sig. } \\
\text { Equal Variances } \\
\text { Assumed }\end{array}$ & 0.826 & Sig. (2-tailed) \\
\hline
\end{tabular}


Based on Table 5, the value of Sig. Levene's Test for Equality of Variances is 0.826 , so the data distribution between the experimental class and the control class is homogeneous. Then the value of Sig. (2-tailed) T-test for Equality of Means was 0.009. Because of the value of Sig. (2-tailed) T-test for Equality of Means is less than 0.05 , so there is a significant difference in the average value of critical thinking skills between the BL class and the conventional class.

The n-gain analysis as a follow-up to the results of the independent sample t-test showed that there was a significant difference between the average value of the experimental class and the control class. The $\mathrm{N}$-gain score was analyzed to determine the effectiveness of BL in terms of students' critical thinking skills. $\mathrm{N}$-gain is an analysis based on improving student performance during learning activities, namely the difference between pretest and posttest scores of critical thinking skills. The results of the n-gain analysis are presented in Table 6 .

Table 6. The results of the n-gain analysis

\begin{tabular}{ccc}
\hline Group & Statistic & Score \\
\hline Control & Mean & 11.30 \\
(Convensional) & Minimum & 0.00 \\
& Maximum & 47.83 \\
Experiment & Mean & 40.21 \\
$(\mathrm{BL})$ & Minimum & 20.00 \\
& Maximum & 83.33 \\
\hline
\end{tabular}

Based on the results of the n-gain score (Table 6.), it can be seen that the average n-gain score for the experimental class (BL) is 40.21 , with a minimum n-gain score of 20 and a maximum n-gain score of 83.33. The average n-gain score for the experimental class (BL) is categorized as less effective. While the average ngain score for the control class (conventional) is 11.30 with a minimum $\mathrm{n}$-gain score of 0 and a maximum ngain score of 47.83 . The average n-gain score for the control class (conventional) is included in the ineffective category.

Based on the students' perceptions of the BL group, most students gave a positive response to the course of learning. As many as $65 \%$ of students think that BL is comfortable for them, this is because they can learn material using videos that feel like explanations from the teacher. This is an indication that students like BL in mathematics lessons. The students' reasons are summarized in Figure 3.

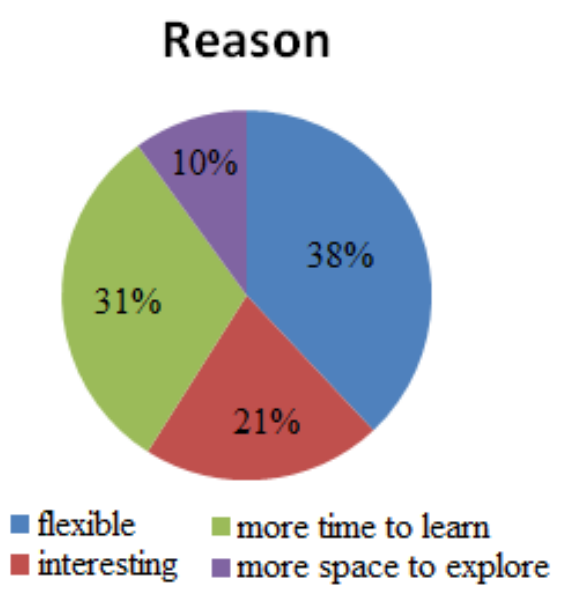

Figure 3. Percentage of students' reasons for liking blended learning

According to most students, BL can be used as alternative learning because it is more interesting. However, some students prefer direct learning, this is because there are several obstacles faced by BL students. There are several obstacles faced by students, especially in online learning, including internet connection, difficulty understanding learning material, and difficulty regulating concentration. 
DOI: https://doi.org/10.24127/ajpm.v10i2.3455

Most of the students in the experimental group thought that $\mathrm{BL}$ could help them learn independently. This is because students can watch videos. After all, videos contain explanations like the teacher does and can be repeated if students lose focus for a moment during learning. Also, online learning is more interesting than learning from reading printed books. Besides, online learning makes it possible to get immediate feedback, so that students can improve their work from the feedback.

Based on the results of the discussion in the section above, it shows that students who learn with BL cannot significantly outperform their peers who learn conventionally. Unlike previously discussed, BL effectively supports students' critical thinking skills than traditional methods (Giacumo \& Savenye, 2019). The results of this study imply that BL is better than conventional learning but not significantly in terms of students' critical thinking skills. If students have freedom in accessing subject matter they can accelerate their learning activities by re-studying the material they have learned. This is different from conventional learning, if students are left behind, it will be difficult to catch up. Even so, it still hasn't shown significant results.

The results of this study are quite different from the results of previous studies. The factors that are considered to be the causes of differences in the results of this study are the obstacles in the implementation of learning and student characteristics. Online learning is expected to facilitate students learning flexibly whenever and wherever but in practice an inadequate internet connection makes online learning difficult and requires extra effort to learn online. Then students with an age range between 12-14 years generally have trouble self-learning. Students' willingness to learn is quite low, students tend to be play-oriented, and self-regulation is less than optimal.

The strength of the online phase is that students can search, browse, and study as much learning material as they need or want, they can also easily repeat teacher explanations in the form of instructional videos. In that process, students actively construct their understanding independently, rather than passively receiving information or subjects from the teacher. The process of BL can effectively improve students' critical thinking skills (Jou et al., 2016). This is supported by the results of interviews where $20 \%$ of the experimental group students like BL because it is flexible in learning time, students can interpret, analyze, and evaluate the material they learn more deeply.

Online feedback and assessments are relatively quick to help students learn. Students who received immediate feedback performed better than those who received delayed feedback or those who did not receive any feedback (Brosvic, Epstein, Cook, \& Dihoff, 2005). With BL, students can get feedback quickly, so it is expected to improve learning outcomes. The interview data support this claim, students are greatly helped by the feedback from the teacher so that they can learn from the feedback, especially when they get the wrong answer.

There are several obstacles in BL according to the opinions expressed by students during the interview. The main problem is an internet connection, before implementing $\mathrm{BL}$ the teacher must ensure that students can easily connect to the internet so that these 
obstacles can be avoided. The next problem is related to student understanding, not all material can be understood directly during online learning, therefore good communication is needed when face-to-face learning takes place. The next problem is a matter of willpower and concentration regulation. Students are often distracted when studying online and lose focus on learning, students need self-regulation to stay on the learning path. This problem is the most difficult problem to solve because it is directly related to the personal will of the student. To reduce this problem, the teacher must try to provide motivation and moral encouragement to students to stay focused on learning activities.

There are several findings in this study. Based on descriptive analysis, it is known that the average value of students' critical thinking in the control class pretest is higher than the experimental class, but changes after the posttest, where the average value of the experimental class increases more than the control class. The final result shows that the BL class is better than the control class in terms of students' critical thinking skills. While the standard deviations in the two classes are not much different in the range of 8.92 - 9.76, this shows that the distribution of scores is quite even, no students get too high or too low scores.

Based on the inferential analysis, it is known that based on the t-test there is a significant difference between the average learning outcomes of the experimental class and the control class, so that there is a better treatment between the two classes. Furthermore, based on the n-gain test, it was found that the treatment in the control class was not effective. While in the experimental class the treatment was categorized as less effective. So it is known that the experimental class is better than the control class, based on inferential analysis. Based on the thematic analysis, $65 \%$ of students claimed to be comfortable in BL learning activities. Students explained that there are four advantages of BL, namely flexible, interesting, more time to learn and more space to explore. BL provides external motivation for students to learn.

Based on the results of the study, it was found that students in the BL class outperformed the students in the control class. There are two reasons suspected to be behind these findings, namely an active learning process and motivation. Student motivation can be seen from the demands of students who claim to be comfortable in their learning activities. While the active learning process is in accordance with previous research that the BL environment applies student-centered learning activities to improve critical thinking skills (Al-Huneidi \& Schreurs, 2013; Broadbent, 2017; Gecer \& Dag, 2012; Poon, 2012).

The benefit of this research is to examine learning activities that are integrated with information technology, namely BL in terms of students' critical thinking skills, especially junior high school students. The weakness in this study is the subject of this study, where the subject of this research is a favorite school student with student abilities above the average and realizes the need for independent study so that it cannot be concluded for general students with average abilities. The implication of this research is theoretically, BL can improve students' critical thinking skills to a certain extent. The implications of implementing $\mathrm{BL}$ can be applied to improve critical thinking skills with 
several conditions. These provisions include student readiness, teacher readiness, and supporting equipment.

\section{CONCLUSION AND SUGGESTION}

The data shows that there are significant differences between BL students and conventional learning students in terms of critical thinking skills, but they are still categorized as less effective. The results of the interview revealed that students had a positive perception of BL even though they faced several obstacles during the implementation of BL. Based on the results of this study, there are significant differences between BL students and conventional learning students. The critical thinking ability of BL students is slightly better than conventional learning students. Student access to the internet, however, should be considered before implementing mixed learning. Another problem relates to generalizability, since the sample was limited to one school with middle-class students, the generalizations drawn from the findings of this study should be carefully considered.

Based on this research, there are several suggestions that can be considered for further BL-themed research. (1) Research on other students' skills such as problem-solving, communication, creativity, etc. (2) BL is still very open for further development. Face-to-face learning can use learning methods such as inquiry, scientific, problem solving, etc. Online learning can be researched about learning media, learning videos, and learning content.

\section{DAFTAR PUSTAKA}

Al-Huneidi, A., \& Schreurs, J. (2013). Constructivism based blended learning in higher education. Communications in Computer and Information Science, 278, 581591. https://doi.org/10.1007/978-3642-35879-1_74

Al-Mubaid, H. (2014). A New Method for Promoting Critical Thinking in Online Education. International Journal of Advanced Corporate Learning (IJAC), 7(4), 34. https://doi.org/10.3991/ijac.v7i4.40 48

Allen, I. E., \& Seaman, J. (2009). Learning on Demand: Online Education in the United States. Online education in the United States (Vol. VII). Newburyport: The Sloan Consortium.

Arends, D., \& Kilcher, A. (2010). Teaching for Student Learning (1st ed.). New York: Routledge. https://doi.org/10.4324/978020386 6771

Bassham, G., Irwin, W., Nardone, H., \& Wallace, J. M. (2011). Critical thinking: A student's introduction (4th ed.). New York: McGrawHill.

Bazelais, P., \& Doleck, T. (2017). Blended learning and traditional learning: A comparative study of college mechanics courses. Educ Inf Technol, (May 1993). https://doi.org/10.1007/s10639018-9748-9

Broadbent, J. (2017). Comparing online and blended learner's selfregulated learning strategies and academic performance. The Internet and Higher Education, 33, 24-32. https://doi.org/10.1016/j.iheduc.20 17.01.004

Brosvic, G. M., Epstein, M. L., Cook, M. J., \& Dihoff, R. E. (2005). Efficacy of Error for the Correction of Initially Incorrect 
Assumptions and of Feedback for the Affirmation of Correct Responding: Learning in the Classroom. The Psychological Record, 55(3), 401-418. https://doi.org/10.1007/BF0339551 8

Cheung, S. K. S., Kwok, L. F., Shang, J., Wang, A., \& Kwan, R. (2016). Blended Learning: Aligning Theory with Practices. (S. K. S. Cheung, L. Kwok, J. Shang, A. Wang, \& R. Kwan, Eds.), Lecture Notes in Computer Science (including subseries Lecture Notes in Artificial Intelligence and Lecture Notes in Bioinformatics) (Vol. 9757). Cham: Springer International Publishing. https://doi.org/10.1007/978-3-31941165-1

Cheung, S. K. S., Kwok, L., Ma, W. W. K., \& Yang, L.-K. L. H. (2017). Blended Learning: New Challenges and Innovative Practices. Springer.

Clark, I., \& James, P. (2012). Blended Learning: An Approach to Delivering Science Courses online. Proceedings of The Australian ..., 19-24. Retrieved from

http://openjournals.library.usyd.ed u.au/index.php/IISME/article/view/ 6430

Ebiendele Ebosele Peter. (2012). Critical thinking: Essence for teaching mathematics and mathematics problem solving skills. African Journal of Mathematics and Computer Science Research, 5(3). https://doi.org/10.5897/AJMCSR1 1.161

Facione, P. A. (2015). Critical Thinking: What It Is and Why It Counts. Insight Assessment.
Retrieved from https://www.insightassessment.co $\mathrm{m} / \mathrm{CT}$-Resources/Teaching-Forand-About-Critical-

Thinking/Critical-Thinking-WhatIt-Is-and-Why-It-Counts/CriticalThinking-What-It-Is-and-Why-ItCounts-PDF

Fong, C. J., Kim, Y., Davis, C. W., Hoang, T., \& Kim, Y. W. (2017). A meta-analysis on critical thinking and community college student achievement. Thinking Skills and Creativity, 26, 71-83. https://doi.org/10.1016/j.tsc.2017.0 6.002

Gecer, A., \& Dag, F. (2012). A blended learning experience. Educational Sciences: Theory and Practice, 12(1), 438-442.

Giacumo, L. A., \& Savenye, W. (2019). Asynchronous discussion forum design to support cognition: effects of rubrics and instructor prompts on learner' $\mathrm{s}$ critical thinking, achievement, and satisfaction. Educational Technology Research and Development, (0123456789). https://doi.org/10.1007/s11423019-09664-5

Herreid, C. F., Schiller, N. A., \& Herreid, K. F. (2012). Science stories: Using case studies to teach critical thinking. , . Arlington, Virginia: NSTA Press. https://doi.org/10.2505/978193613 7251

Johnson, E. B. (2002). Contextual teaching and learning: What it is and why it's here to stay. California: Corwin Press. https://doi.org/10.5860/choice.401053

Jou, M., Lin, Y. T., \& Wu, D. W. (2016). Effect of a blended learning environment on student 
DOI: https://doi.org/10.24127/ajpm.v10i2.3455

critical thinking and knowledge transformation. Interactive Learning Environments, 24(6), 1131-1147.

https://doi.org/10.1080/10494820.2 014.961485

Kashefi, H., Ismail, Z., Mohammad, Y., \& Abdul, R. (2012). Supporting students mathematical thinking in the learning of two-variable functions through blended learning. Procedia - Social and Behavioral Sciences, 46(2004), 3689-3695.

https://doi.org/10.1016/j.sbspro.20 12.06.128

Kemdikbud. Rencana Strategis Kementerian Pendidikan dan Kebudayaan Tahun 2015-2019 (2015). Indonesia. Retrieved from https://e-

ppid.kemdikbud.go.id/dokumen/pe rmendikbud-12-2018-renstra.pdf

Kwan, Y. W., \& Wong, A. F. L. (2015). Effects of the constructivist learning environment on students' critical thinking ability: Cognitive and motivational variables as mediators. International Journal of Educational Research, 70, 68-79. https://doi.org/10.1016/j.ijer.2015. 02.006

Mason, M. (2008). Critical Thinking and Learning. Blackwell Publishing.

Monk, E. F., Guidry, K. R., Pusecker, K. L., \& Ilvento, T. W. (2019). Blended learning in computing education: It's here but does it work? Education and Information Technologies. https://doi.org/10.1007/s10639019-09920-4
Moore, B. N., \& Parker, R. (2015). Critical Thinking (11th ed.). New York: McGraw-Hill.

Nitko, A. J., \& Brookhart, S. M. (2014). Educational assessment of students pearson new international edition (6th ed.). Pearson.

Nuri, B. (2019). Why are mathematics teachers advised to use blended learning in the learning process? Journal of Physics: Conference Series, 1397(1). https://doi.org/10.1088/17426596/1397/1/012080

Poon, J. (2012). Use of blended learning to enhance the student learning experience and engagement in property education. Property Management, 30(2), 129-156.

Yeen-ju, H. T., Mai, N., \& Selvaretnam, B. (2015). Enhancing ProblemSolving Skills in an Authentic Blended Learning Environment : A Malaysian Context. International Journal of Information and Education Technology, 5(11). https://doi.org/10.7763/IJIET.2015. V5.623 